\title{
Innovation in the teaching-learning process of global climate change through the collaborative wall
}

\author{
Ricardo-Adán Salas-Rueda1 ${ }^{1}$, Gustavo De-La-Cruz-Martínez¹, \\ Clara Alvarado-Zamorano ${ }^{1}$ and Estefanía Prieto-Larios ${ }^{2}$ \\ ${ }^{1}$ Instituto de Ciencias Aplicadas y Tecnología, Universidad Nacional Autónoma de México, México \\ ${ }^{2}$ Facultad de Ciencias, Universidad Nacional Autónoma de México, México
}

The aim of this mixed research is to analyze the students' perception about the use of the collaborative wall in the educational process of global climate change considering data science. The collaborative wall is a web application that allows the active participation of students and discussion of ideas in the classroom. During the face-to-face sessions, the students use mobile devices to share the information and images of the courses through the collaborative wall. The sample is made up of 74 students from the National Preparatory School No. 7 "Ezequiel A. Chávez" who took the Biology IV course during the 2019 school year. The results of machine learning (linear regression) indicate that the organization of ideas and dissemination of information in the collaborative wall positively influence the learning process of global climate change, motivation and interest of the students. Data science identifies 6 predictive models about the use of the collaborative wall in the field of Biology through the decision tree technique. In fact, the use of the collaborative wall in the Biology IV course facilitated the assimilation of knowledge about the global climate change and improved the active participation of the students in the classroom. Finally, the collaborative wall allows the creation of new educational spaces where students acquire the main role during the learning process.
ARTICLE DETAILS

LUMAT General Issue

Vol 9 No 1 (2021), 256-282

Received 24 December 2020 Accepted 12 April 2021 Published 3 May 2021

Pages: 27

References: 27

Correspondence: mricardo.salas@icat.unam.mx

https://doi.org/10.31129/ LUMAT.9.1.1471

Keywords: collaborative wall, learning, data science, machine learning, global

climate change

\section{Introduction}

Today, universities are using technological advances such as educational platforms, digital tools and web applications during the organization of courses in order to develop the students' skills (Almoeather, 2020; Zhang, 2018). In fact, teachers use Information and Communication Technologies (ICTs) to create new virtual spaces that facilitate the learning process at home and participation of students in the classroom (Almoeather, 2020; Benitez et al., 2020).

The incorporation of technological tools and software in the educational context increases the motivation and satisfaction of students during the performance of the school activities (Benitez et al., 2020; Elekaei, Tabrizi, \& Chalak, 2020; Galimullina, Ljubimova, \& Ibatullin, 2020). Also, teachers use technology to promote the active role of students inside and outside the classroom (Benitez et al., 2020; Shen et al., 2020; Whalley \& Barbour, 2020). 
In the 21st century, the Internet plays a fundamental role in the educational field (Bidarra \& Rusman, 2017; Paepe, Zhu, \& Depryck, 2018; Elekaei, Tabrizi, \& Chalak, 2020; Salas-Rueda, 2018). During the innovation of the learning process, teachers are incorporating web applications in the school activities to encourage the active role of students (Appleton \& Mackie, 2019; Manrique et al., 2017). For example, the collaborative wall is a web application that allows the active participation of students and discussion of ideas in the classroom through the organization, dissemination and use of images and information (Salas-Rueda, Ramírez-Ortega, \& Eslava-Cervantes, 2021).

In the Biology IV course, the students have a passive role during the realization of the school activities and present difficulties to understand the topics. In fact, the exchange of ideas, collaborative work and discussion of contents in the classroom is rare in this course. Therefore, this mixed research proposes the incorporation of the collaborative wall in the teaching-learning process of global climate change. The research questions are:

- What is the impact of the use of collaborative wall in the learning process of global climate change, motivation and interest of the students?

- What are the predictive models about the use of the collaborative wall in the educational process about biology?

- What are the perceptions of students about the use of the collaborative wall in the school activities?

\section{Use of technology in the educational field}

Technological advances are changing the organization of school activities inside and outside the classroom (Benitez et al., 2020). In fact, the incorporation of ICTs in the educational field transformed the teaching-learning conditions and improved the courses of English Language (Benitez et al., 2020; Elekaei, Tabrizi, \& Chalak, 2020), Geometric Representation Systems (Salas-Rueda, Ramírez-Ortega, \& EslavaCervantes, 2021), Biology (Manrique et al., 2017; Poli et al., 2016; Shen et al., 2020), Financial accounting (Han, 2018), Costs (Zhang, 2018) and Computer science (SalasRueda, 2020).

In the field of Computer science, the use of MySQL software transformed the role of the students and facilitated the learning process about database issues (SalasRueda, 2020). In the classroom, these students worked as a team and used the MySQL 
software to link the theoretical concepts on the database with the productive field (Salas-Rueda, 2020). After the class, the students of the Database course solved the laboratory practices using the MySQL software (Salas-Rueda, 2020).

In the English language courses, the use of the Nota Bene software facilitated the collaborative work among the students and teacher through the dissemination of opinions and comments (Benitez et al., 2020). This software transformed the teaching-learning process through the presentation of multimedia resources and elaboration of comments (Benitez et al., 2020). The benefits of Nota Bene software in the educational field are the interaction between the participants of the educational process and increase of the academic performance (Benitez et al., 2020).

In the same way, the use of technology in Foreign Language courses facilitated the creation and organization of new school activities (Benitez et al., 2020; Elekaei, Tabrizi, \& Chalak, 2020). In particular, the students of the English Language course developed their vocabulary skills through the consultation of podcast and review of animations (Elekaei, Tabrizi, \& Chalak, 2020). Even the incorporation of ICTs in this course allowed the personalization of the learning process (Elekaei, Tabrizi, \& Chalak, 2020).

Han (2018) built an educational web system in order to facilitate the teachinglearning process about financial accounting. In fact, the students actively participated by consulting the audiovisual contents about finance and holding the discussion forums in this educational web system (Han, 2018). Also, the incorporation of technology in the Introduction to Financial Accounting course caused an increase of the academic performance and motivation of the students (Han, 2018).

In the same way, Zhang (2018) designed and built a technological application in order to facilitate the learning process about accounting. The students used this technological application to facilitate the assimilation of knowledge about cost issues through the visualization of the mathematical procedure (Zhang, 2018). In addition, the use of technology in the Costs course allowed the development of mathematical skills (Zhang, 2018).

The collaborative wall allows transforming the behavior of teachers and the role of students during the performance of the school activities in the classroom (SalasRueda, Ramírez-Ortega, \& Eslava-Cervantes, 2021). In the Geometric Representation Systems course, the students used the collaborative wall to exchange ideas with their classmates and discuss the information with the teacher (Salas-Rueda, RamírezOrtega, \& Eslava-Cervantes, 2021). 
ICTs are changing the roles of students and teacher inside and outside the classroom (Han, 2018; Wang \& Fan, 2018). In particular, the creation of new virtual educational spaces encourages the active role of students at any time and place (Elekaei, Tabrizi, \& Chalak, 2020; Han, 2018; Xia, 2018).

\subsection{Technology in the educational process about Biology}

Technology has improved the teaching-learning conditions in the field of Biology (Appleton \& Mackie, 2019; Poli et al., 2016; Shen et al., 2020). For example, teachers used ICTs to create new educational spaces that facilitated the assimilation of knowledge about infectious diseases (Shen et al., 2020), anatomy (Manrique et al., 2017), protein evolution (Poli et al., 2016), biodiversity (Lysne \& Miller, 2015) and biological evolution (Appleton \& Mackie, 2019).

Shen et al. (2020) built a website called "Find the Source of Infection" in order to facilitate the exchange of ideas about the ways of transmission of diseases. This website facilitated the assimilation of knowledge about the origin of infections and improved the communication between the teacher and students through the use of mobile devices (Shen et al., 2020).

Augmented reality plays a fundamental role to improve the teaching-learning conditions in the field of Biology (Manrique et al., 2017). In the Anatomy course, the students used an augmented reality application to facilitate the learning process about the distribution of bones, muscles and organs in the human body (Manrique et al., 2017). The incorporation of technology in the Anatomy course increased the motivation, satisfaction and academic performance of the students (Manrique et al., 2017).

In the Biodiversity course, mobile devices facilitated the active participation of the students inside and outside the classroom (Lysne \& Miller, 2015). In particular, smartphones allowed the capture of images about organisms and dissemination of this information (Lysne \& Miller, 2015). The students of the Biodiversity course improved their academic performance on the morphology of organisms by analyzing the images obtained from mobile devices (Lysne \& Miller, 2015).

Poli et al. (2016) proposed the use of MapBox Studio software in the field of Biology in order to promote the active role of the students during the teachinglearning process. In particular, this software facilitated the assimilation of knowledge about the evolution of the protein (Poli et al., 2016). 
On the other hand, Appleton and Mackie (2019) explain that the incorporation of technological applications facilitated the assimilation of knowledge about biological evolution. For example, the Earth application improved the learning process related to evolution, population balance problems and natural selection (Appleton \& Mackie, 2019). Likewise, the Biomorphs application facilitated the assimilation of knowledge about the gradual process of biological evolution through the use of simulations (Appleton \& Mackie, 2019).

Lastly, the use of technology in the field of Biology allows innovating the courses, updating the school activities carried out inside and outside the classroom, increasing the motivation of students and improving the academic performance (Lysne \& Miller, 2015; Manrique et al., 2017; Poli et al., 2016).

\subsection{Use of the virtual wall in the educational field}

Today, technological advances allow that teachers build new educational virtual spaces where students play a fundamental role during the learning process (PardoCueva et al., 2020; Salas-Rueda, Ramírez-Ortega, \& Eslava-Cervantes, 2021). For example, Padlet is a virtual wall that promotes the active role of students inside and outside the classroom (De-Witt et al., 2015; Pardo-Cueva et al., 2020; Rashid, Yunus, \& Wahi, 2019; Sangeetha, 2016).

Virtual walls allow the organization of collaborative activities before, during and after the face-to-face sessions (Pardo-Cueva et al., 2020; Rashid, Yunus, \& Wahi, 2019). In the Administration course, the use of Padlet favored the collaborative work, improved academic performance and increased the satisfaction of the students during the teaching-learning process (Pardo-Cueva et al., 2020). In the same way, the incorporation of the collaborative wall in the Geometric Representation Systems course facilitated the participation of the students during the face-to-face sessions (Salas-Rueda, Ramírez-Ortega, \& Eslava-Cervantes, 2021).

Teachers use virtual walls to build new educational spaces that facilitate collaborative work and participation in the classroom (De-Witt et al., 2015; Rashid, Yunus, \& Wahi, 2019; Sangeetha, 2016). In the Foreign Language course, the use of Padlet promoted autonomy, increased motivation and decreased the anxiety of the students during the teaching-learning process (Rashid, Yunus, \& Wahi, 2019). Also, this technological tool allowed collaborative work during the face-to-face sessions and development of writing and communication skills about the English Language (Rashid, Yunus, \& Wahi, 2019). 
The benefits of the use of virtual walls in the educational field are the publication of information, storage of data and dissemination of school contents (Pardo-Cueva et al., 2020; Rashid, Yunus, \& Wahi, 2019). According to Sangeetha (2016), the incorporation of Edmodo and Padlet facilitated the dissemination of information, improved the learning process about the English Language and developed their writing skills. Similarly, the collaborative wall and mobile devices facilitated the exchange of ideas in the Social Sciences course (Salas-Rueda et al., 2020).

Finally, virtual walls such as Padlet and the collaborative wall have transformed the teaching-learning process in the courses of Administration (Pardo-Cueva et al., 2020), Geometric Representation Systems (Salas-Rueda, Ramírez-Ortega, \& EslavaCervantes, 2021), Foreign Language (Rashid, Yunus, \& Wahi, 2019; Sangeetha, 2016) and Social Sciences (Salas-Rueda et al., 2020).

\section{Methodology}

The particular aims of this mixed research are (1) analyze the impact of the use of collaborative wall in the learning process of global climate change, (2) analyze the impact of the use of collaborative wall in the motivation of the students, (3) analyze the impact about the use of the collaborative wall in the interest of the students, (4) identify the predictive models about the use of the collaborative wall in the educational process about biology and (5) analyze the perceptions of the students about the use of the collaborative wall in the Biology IV course.

\subsection{Participants}

The sample is made up of 74 students (29 men and 45 women) from the National Preparatory School No. 7 "Ezequiel A. Chávez" who took the Biology IV course during the 2019 school year. This course belongs to the fifth year of high school. The average age is 16.89 years.

\subsection{Procedure}

The teacher of the Biology IV course took the Classroom of the Future 2019 Diploma offered by the National Autonomous University of Mexico (NAUM) with the purpose of training in the topics related to pedagogy and the use of technology. This diploma uses the pedagogical model proposed by Gamboa-Rodríguez (2015) and the collaborative wall to innovate the teaching-learning process (See Figure 1). 


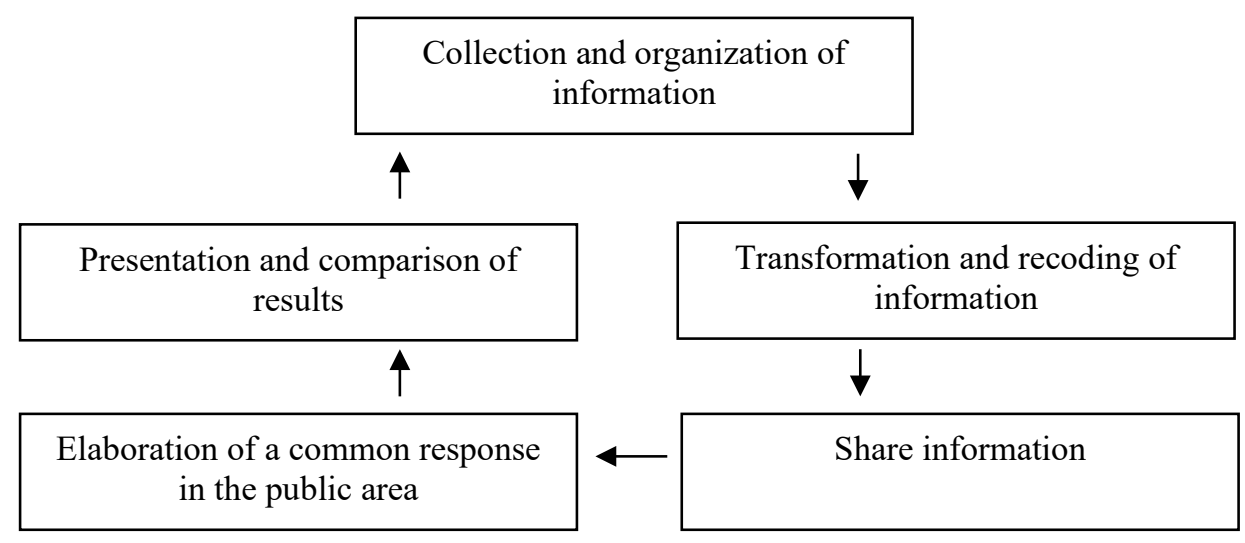

Figure 1. Pedagogical model proposed by Gamboa-Rodríguez (2015).

In the Institute of Applied Sciences and Technology of the NAUM, GamboaRodríguez built the collaborative wall in order to improve the teaching-learning conditions and facilitate the active role of students during the face-to-face sessions (See Figure 2). The collaborative wall is a web application that allows the active participation of students and discussion of ideas in the classroom through the organization, dissemination and use of images and text.

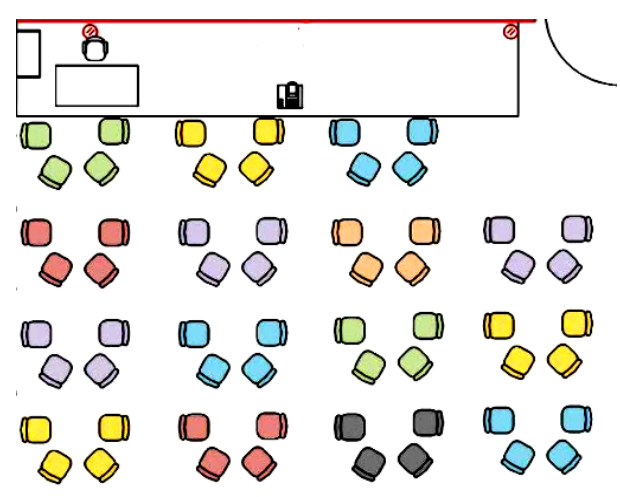

(a) Distribution in the classroom

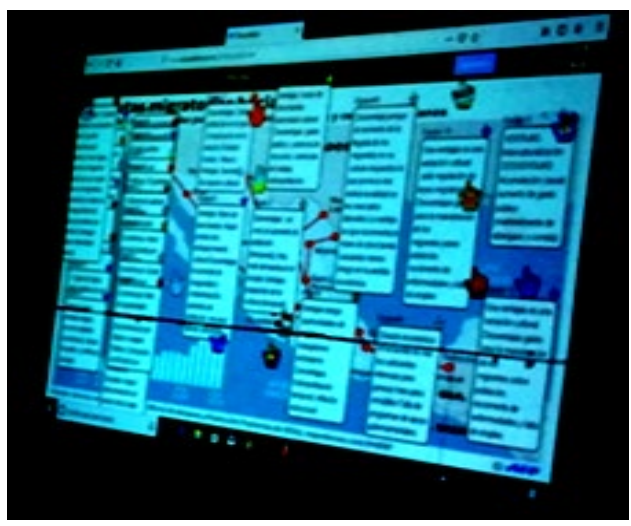

(b) Images and text in the collaborative

Figure 2. Example about the use of the collaborative wall.

Table 1 shows the educational context of the Biology IV course at the National Preparatory School No. 7 "Ezequiel A. Chávez”. 
Table 1. Educational context.

\begin{tabular}{|c|c|c|c|}
\hline No. & Aspect & Item & Description \\
\hline \multirow{3}{*}{1} & \multirow{3}{*}{ Analysis } & Problem & $\begin{array}{l}\text { In the Biology IV course, the students have a passive role } \\
\text { during the realization of the school activities and present } \\
\text { difficulties to understand the topics. In fact, the } \\
\text { exchange of ideas, collaborative work and discussion of } \\
\text { contents in the classroom is rare in this course. }\end{array}$ \\
\hline & & $\begin{array}{l}\text { Characteristics of } \\
\text { the students }\end{array}$ & $\begin{array}{l}\text { The students attended the fifth year of high school at the } \\
\text { National Preparatory School No. } 7 \text { "Ezequiel A. Chávez" }\end{array}$ \\
\hline & & Technology & $\begin{array}{l}\text { The teacher of the Biology IV course does not use ICTs } \\
\text { during the teaching-learning process on global climate } \\
\text { change }\end{array}$ \\
\hline \multirow[b]{2}{*}{2} & \multirow[b]{2}{*}{ Design } & $\begin{array}{l}\text { Learning } \\
\text { objectives }\end{array}$ & $\begin{array}{l}\text { Know the concept of global climate change } \\
\text { Understand the factors that influence the global climate } \\
\text { change } \\
\text { Analyze the impact of global climate change on the } \\
\text { society }\end{array}$ \\
\hline & & Use of technology & $\begin{array}{l}\text { The collaborative wall is a web application that allows } \\
\text { the active participation of students and discussion of } \\
\text { ideas in the classroom } \\
\text { During the face-to-face sessions, the students use mobile } \\
\text { devices to share the information and images of the } \\
\text { courses through the collaborative wall }\end{array}$ \\
\hline \multirow[b]{2}{*}{3} & \multirow[b]{2}{*}{ Development } & $\begin{array}{l}\text { Before the face- } \\
\text { to-face sessions }\end{array}$ & $\begin{array}{l}\text { The students of the National Preparatory School No. } 7 \\
\text { "Ezequiel A. Chávez" searched and analyzed the } \\
\text { information about the global climate change at home }\end{array}$ \\
\hline & & $\begin{array}{l}\text { During the face- } \\
\text { to-face sessions }\end{array}$ & $\begin{array}{l}\text { The students of the National Preparatory School No. } 7 \\
\text { "Ezequiel A. Chávez" used mobile devices to enter the } \\
\text { information about the global climate change in the } \\
\text { collaborative wall and continue with the discussion of } \\
\text { the topics in the classroom }\end{array}$ \\
\hline \multirow[t]{2}{*}{4} & \multirow[t]{2}{*}{ Implementation } & $\begin{array}{l}\text { Face-to-face } \\
\text { sessions }\end{array}$ & 3 face-to-face sessions \\
\hline & & Duration & 50 minutes in each face-to-face session \\
\hline
\end{tabular}

Before the face-to-face sessions, the students of the National Preparatory School No. 7 "Ezequiel A. Chávez" searched, selected and analyzed the information about the global climate change at home. In the classroom, the teacher of the Biology IV course used the computer and Internet to access the collaborative wall. Also, the video projector displayed the workspace of the collaborative wall.

The teacher of the Biology IV course started the discussion forum in order to promote the active role of the students. Later, the students of the National Preparatory School No. 7 "Ezequiel A. Chávez" used mobile devices to enter the information about 
the global climate change in the collaborative wall and continue with the debate of the topics (See Figure 3).

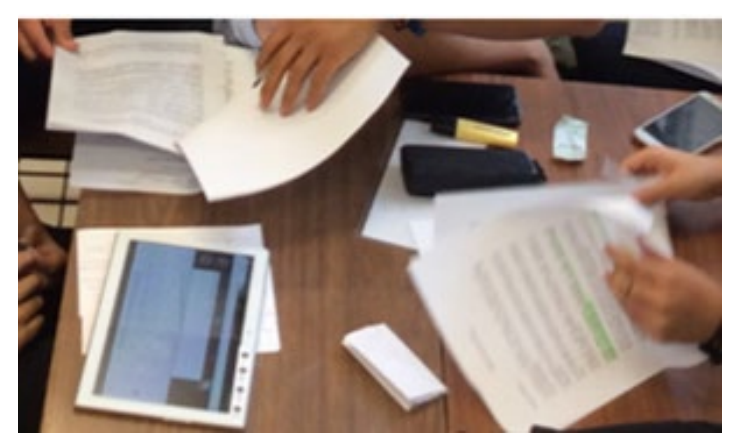

Figure 3. Use of mobile devices to enter in the collaborative wall.

Figure 4 shows the model used to analyze the impact of the collaborative wall in the Biology IV course. In particular, machine learning allows analyzing the use of this technological tool in the learning process of global climate change, motivation and interest of the students through linear regressions.
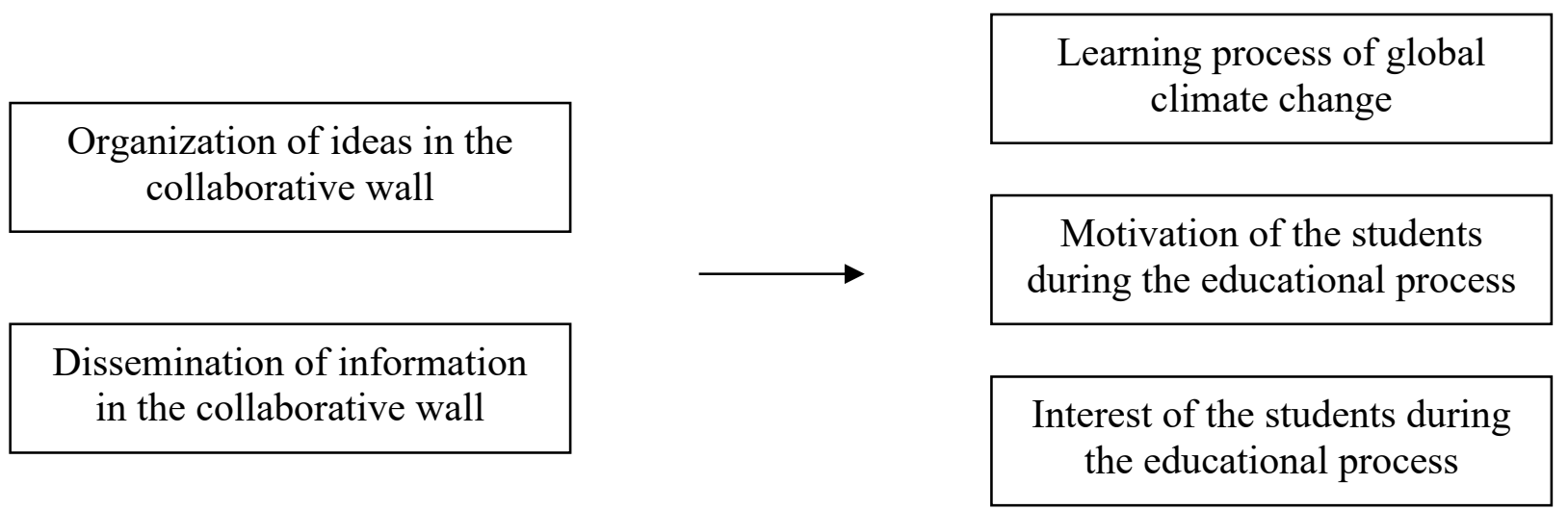

Figure 4. Model about the use of the collaborative wall in the Biology IV course.

The incorporation of technological advances in the educational field of Biology facilitates the learning process (Appleton \& Mackie, 2019; Shen et al., 2020). Therefore, the hypotheses about the use of the collaborative wall and learning process are:

- Hypothesis 1 (H1): The organization of ideas in the collaborative wall positively influences the learning process of global climate change 
- Hypothesis 2 (H2): The dissemination of information in the collaborative wall positively influences the learning process of global climate change

Teachers of the Biology courses use technology to increase the motivation of students (Manrique et al., 2017; Shen et al., 2020). Therefore, the hypotheses about the use of the collaborative wall and motivation of the students are:

- Hypothesis $3\left(\mathrm{H}_{3}\right)$ : The organization of ideas in the collaborative wall positively influences the motivation of the students during the educational process of global climate change

- Hypothesis 4 ( $\left.\mathrm{H}_{4}\right)$ : The dissemination of information in the collaborative wall positively influences the motivation of the students during the educational process of global climate change

In Biology courses, teachers use ICTs to build new educational spaces (Lysne \& Miller, 2015; Shen et al., 2020). Therefore, the hypotheses about the use of the collaborative wall and the interest of students during the educational process are:

- Hypothesis $5\left(\mathrm{H}_{5}\right)$ : The organization of ideas in the collaborative wall positively influences the interest of the students during the educational process of global climate change

- Hypothesis 6 (H6): The dissemination of information in the collaborative wall positively influences the interest of the students during the educational process of global climate change

On the other hand, the predictive models about the use of the collaborative wall in the educational process of Biology are:

- Predictive Model 1 (PM1) about the organization of ideas in the collaborative wall and learning process of global climate change

- Predictive Model 2 (PM2) about the dissemination of information in the collaborative wall and learning process of global climate change

- Predictive Model 3 ( $\mathrm{PM}_{3}$ ) about the organization of ideas in the collaborative wall and motivation of the students during the educational process of global climate change

- Predictive Model 4 ( $\mathrm{PM}_{4}$ ) about the dissemination of information in the collaborative wall and motivation of the students during the educational process of global climate change 
- Predictive Model 5 (PM5) about the organization of ideas in the collaborative wall and interest of the students during the educational process of global climate change

- Predictive Model 6 (PM6) about the dissemination of information in the collaborative wall and interest of the students during the educational process of global climate change

\subsection{Data collection}

Data collection was carried out at the National Preparatory School No. 7 "Ezequiel A. Chávez" during the month of November 2019. Table 2 shows the questionnaire used to retrieve the information about the use of the wall in the educational process of Biology.

Table 2. Questionnaire about the use of the collaborative wall.

\begin{tabular}{|c|c|c|c|c|c|c|}
\hline No. & Variable & Dimension & Question & Answer & $n$ & $\%$ \\
\hline \multirow{7}{*}{1} & \multirow{7}{*}{$\begin{array}{l}\text { Profile of the } \\
\text { students }\end{array}$} & \multirow{5}{*}{ Age } & \multirow[t]{5}{*}{ 1. Indicate your age } & 15 years & 5 & $6.76 \%$ \\
\hline & & & & 16 years & 48 & $64.86 \%$ \\
\hline & & & & 17 years & 14 & $18.92 \%$ \\
\hline & & & & 18 years & 4 & $5.41 \%$ \\
\hline & & & & $>18$ years & 3 & $4.05 \%$ \\
\hline & & \multirow{2}{*}{ Sex } & \multirow[t]{2}{*}{ 2. Indicate your sex } & Man & 29 & $39.19 \%$ \\
\hline & & & & Woman & 45 & $60.81 \%$ \\
\hline \multirow{20}{*}{2} & \multirow{20}{*}{$\begin{array}{l}\text { Collaborative } \\
\text { wall }\end{array}$} & \multirow{4}{*}{$\begin{array}{l}\text { Organization of } \\
\text { ideas }\end{array}$} & \multirow{4}{*}{$\begin{array}{l}\text { 3. The collaborative wall facilitates } \\
\text { the organization of ideas }\end{array}$} & Very much (1) & 59 & $79.73 \%$ \\
\hline & & & & Much (2) & 11 & $14.86 \%$ \\
\hline & & & & Little (3) & 4 & $5.41 \%$ \\
\hline & & & & Very little (4) & 0 & $0.00 \%$ \\
\hline & & \multirow{4}{*}{$\begin{array}{l}\text { Dissemination of } \\
\text { information }\end{array}$} & \multirow{4}{*}{$\begin{array}{l}\text { 4. The collaborative wall facilitates } \\
\text { the dissemination of information }\end{array}$} & Very much (1) & 57 & $77.03 \%$ \\
\hline & & & & Much (2) & 12 & $16.22 \%$ \\
\hline & & & & Little (3) & 5 & $6.76 \%$ \\
\hline & & & & Very little (4) & 0 & $0.00 \%$ \\
\hline & & \multirow{4}{*}{ Learning process } & \multirow{4}{*}{$\begin{array}{l}\text { 5. The use of the collaborative wall } \\
\text { facilitates the learning process of } \\
\text { global climate change }\end{array}$} & Very much (1) & 53 & $71.62 \%$ \\
\hline & & & & Much (2) & 13 & $17.57 \%$ \\
\hline & & & & Little (3) & 5 & $6.76 \%$ \\
\hline & & & & Very little (4) & 3 & $4.05 \%$ \\
\hline & & \multirow{4}{*}{$\begin{array}{l}\text { Motivation of } \\
\text { students }\end{array}$} & \multirow{4}{*}{$\begin{array}{l}\text { 6. The use of the collaborative wall } \\
\text { increases the motivation of the } \\
\text { students during the educational } \\
\text { process of global climate change }\end{array}$} & Very much (1) & 49 & $66.22 \%$ \\
\hline & & & & Much (2) & 13 & $17.57 \%$ \\
\hline & & & & Little (3) & 5 & $6.76 \%$ \\
\hline & & & & Very little (4) & 7 & $9.46 \%$ \\
\hline & & \multirow{4}{*}{$\begin{array}{l}\text { Interest of } \\
\text { students }\end{array}$} & \multirow{4}{*}{$\begin{array}{l}\text { 7. The use of the collaborative wall } \\
\text { increases the interest of the } \\
\text { students during the educational } \\
\text { process of global climate change }\end{array}$} & Very much (1) & 45 & $60.81 \%$ \\
\hline & & & & Much (2) & 19 & $25.68 \%$ \\
\hline & & & & Little (3) & 8 & $10.81 \%$ \\
\hline & & & & Very little (4) & 2 & $2.70 \%$ \\
\hline 3 & $\begin{array}{l}\text { Students' } \\
\text { perception }\end{array}$ & $\begin{array}{l}\text { Use of the } \\
\text { collaborative wall }\end{array}$ & $\begin{array}{l}\text { 8. What is your opinion about the } \\
\text { use of the collaborative wall? }\end{array}$ & Open & - & - \\
\hline
\end{tabular}


The values of Load Factor ( $>$ 0.500), Alpha Cronbach ( $>$ 0.600) and Composite Reliability ( $>0.700$ ) are necessary to validate the measurement instrument. Table 3 shows that the values of Load Factor ( $>0.519$ ), Alpha Cronbach ( $>0.780$ ) and Composite Reliability ( $>0.870$ ) allow to validate the questionnaire about the use of the collaborative wall.

Table 3. Validation of the questionnaire about the use of the collaborative wall.

\begin{tabular}{llllll}
\hline Variable & Dimension & $\begin{array}{l}\text { Load } \\
\text { Factor }\end{array}$ & $\begin{array}{l}\text { Alpha } \\
\text { Cronbach }\end{array}$ & $\begin{array}{l}\text { Average } \\
\text { Variance } \\
\text { Extracted }\end{array}$ & $\begin{array}{l}\text { Composite } \\
\text { Reliability }\end{array}$ \\
\hline \multirow{3}{*}{ Collaborative } & Organization of ideas & 0.742 & & & \\
wall & Dissemination of information & 0.804 & & & \\
& Learning process & 0.520 & 0.790 & 0.581 & \\
& Motivation of students & 0.850 & & & \\
& Interest of students & 0.846 & & & \\
\hline
\end{tabular}

\subsection{Data analysis}

The Rapidminer tool allows data analysis through the construction of predictive models and calculation of machine learning (linear regression). In particular, the information of the student's profile (sex and age) and use of the collaborative wall allows the construction of predictive models by means of the decision tree technique. Also, the criterion for creating these models is the Gini index.

In machine learning, the training section (50\%, 60\% and $70 \%$ of the sample) allows the calculation of linear regressions to evaluate the hypotheses about the use of the collaborative wall in the field of Biology, and the evaluation section (50 \%, 40\% and $30 \%$ of the sample) allows identifying the accuracy of these linear regressions by means of the squared error.

\section{Results}

The collaborative wall allows the construction of new educational spaces where students participates actively during the learning process. In fact, the collaborative wall facilitates very much $(\mathrm{n}=59,79.73 \%)$, much $(\mathrm{n}=11,14.86 \%)$ and little $(\mathrm{n}=4$, $5.41 \%$ ) the organization of ideas (See Table 2). Likewise, the collaborative wall facilitates very much $(n=57,77.03 \%)$, much $(n=12,16.22 \%)$ and little $(n=5,6.76 \%)$ the dissemination of information.

The results of machine learning (linear regression) indicate that the organization of ideas and dissemination of information in the collaborative wall positively influence 
the learning process of global climate change, motivation and interest of the students (See Table 4).

Table 4. Results of machine learning.

\begin{tabular}{lcccc}
\hline \multicolumn{1}{c}{ Hypothesis } & Training & Linear regression & Conclusion & $\begin{array}{c}\text { Error } \\
\text { squared }\end{array}$ \\
\hline H1: Organization of ideas in the & $50 \%$ & $y=0.131 x+1.325$ & Accepted: 0.131 & 1.014 \\
collaborative wall $\rightarrow$ learning & $60 \%$ & $y=0.160 x+1.163$ & Accepted: 0.160 & 1.260 \\
process & $70 \%$ & $y=0.154 x+1.204$ & Accepted: 0.154 & 1.204 \\
\hline H2: Dissemination of information in & $50 \%$ & $y=0.199 x+1.168$ & Accepted: 0.199 & 0.661 \\
the collaborative wall $\rightarrow$ learning & $60 \%$ & $y=0.216 x+1.119$ & Accepted: 0.216 & 0.775 \\
process & $70 \%$ & $y=0.246 x+1.038$ & Accepted: 0.246 & 1.024 \\
\hline H3: Organization of ideas in the & $50 \%$ & $y=0.726 x+0.787$ & Accepted: 0.726 & 0.625 \\
collaborative wall $\rightarrow$ motivation of & $60 \%$ & $y=0.629 x+0.911$ & Accepted: 0.629 & 0.507 \\
students & $70 \%$ & $y=0.679 x+0.836$ & Accepted: 0.679 & 0.379 \\
\hline H4: Dissemination of information in & $50 \%$ & $y=0.584 x+0.955$ & Accepted: 0.584 & 0.558 \\
the collaborative wall $\rightarrow$ motivation & $60 \%$ & $y=0.731 x+0.745$ & Accepted: 0.731 & 0.549 \\
of students & $70 \%$ & $y=0.766 x+0.694$ & Accepted: 0.766 & 0.461 \\
\hline H5: Organization of ideas in the & $50 \%$ & $y=0.675 x+0.826$ & Accepted: 0.675 & 0.498 \\
collaborative wall $\rightarrow$ interest of & $60 \%$ & $y=0.583 x+0.949$ & Accepted: 0.583 & 0.338 \\
students & $70 \%$ & $y=0.594 x+0.907$ & Accepted: 0.594 & 0.276 \\
\hline H6: Dissemination of information in & $50 \%$ & $y=0.678 x+0.804$ & Accepted: 0.678 & 0.355 \\
the collaborative wall $\rightarrow$ interest of & $60 \%$ & $y=0.806 x+0.622$ & Accepted: 0.806 & 0.345 \\
students & $70 \%$ & $y=0.800 x+0.611$ & Accepted: 0.800 & 0.298 \\
\hline
\end{tabular}

Table 5 shows the Pearson's correlations about the use of the collaborative wall in the field of Biology.

Table 5. Pearson's correlations about of the collaborative wall.

\begin{tabular}{lccccc}
\hline & $\begin{array}{c}\text { Organization } \\
\text { of ideas }\end{array}$ & $\begin{array}{c}\text { Dissemination } \\
\text { of information }\end{array}$ & $\begin{array}{c}\text { Learning } \\
\text { process }\end{array}$ & $\begin{array}{c}\text { Motivation } \\
\text { of students }\end{array}$ & $\begin{array}{c}\text { Interest of } \\
\text { students }\end{array}$ \\
\hline Organization of ideas & 1 & - & - & - & - \\
Dissemination of information & 0.647 & 1 & - & - & - \\
Learning process & 0.087 & 0.160 & 1 & - & - \\
Motivation of students & 0.476 & 0.496 & 0.260 & 1 & - \\
Interest of students & 0.452 & 0.577 & 0.265 & 0.732 & 1 \\
\hline
\end{tabular}




\subsection{Learning process}

The use of the collaborative wall facilitates very much $(\mathrm{n}=53,71.62 \%)$, much $(\mathrm{n}=13$, $17.57 \%)$, little $(n=5,6.76 \%)$ and very little $(n=3,4.05 \%)$ the learning process of global climate change (See Table 2). The results of machine learning with 50\% (0.131), $60 \%(0.160)$ and $70 \%$ (0.154) of training indicate that $\mathrm{H} 1$ is accepted (See Table 4). Therefore, the organization of ideas in the collaborative wall positively influences the learning process of global climate change.

Table 6 presents the 9 conditions of the PM1 with the accuracy of $74.32 \%$. For example, if the student thinks that the collaborative wall facilitates much the organization of ideas, has an age $\leq 17.5$ years and is a woman then the use of the collaborative wall facilitates much the learning process of global climate change. On the other hand, if the student thinks that the collaborative wall facilitates very much the organization of ideas and has an age $\leq 17.5$ years then the use of the collaborative wall facilitates very much the learning process of global climate change.

Table 6. Conditions of the PM1 about the use of the collaborative wall.

\begin{tabular}{ccccc}
\hline No. & $\begin{array}{c}\text { Collaborative wall } \rightarrow \\
\text { organization of ideas }\end{array}$ & Age & Sex & $\begin{array}{c}\text { Collaborative wall } \rightarrow \\
\text { learning process }\end{array}$ \\
\hline 1 & Very much & $\leq 17.5$ years & - & Very much \\
2 & Very much & $>17.5$ years & Man & Very much \\
3 & Very much & $>19.5$ years & Woman & Very much \\
4 & Very much & $\leq 19.5 \&>17.5$ years & Woman & Very little \\
5 & Much & $>17.5$ years & - & Very much \\
6 & Much & $\leq 17.5 \&>16.5$ years & Man & Much \\
7 & Much & $\leq 16.5$ years & Man & Very much \\
8 & Much & $\leq 17.5$ years & Woman & Much \\
9 & Little & - & - & Very much \\
\hline
\end{tabular}

The results of machine learning with 50\% (0.199), 60\% (0.216) and 70\% (0.246) of training indicate that $\mathrm{H}_{2}$ is accepted (See Table 4). Therefore, the dissemination of information in the collaborative wall positively influences the learning process of global climate change.

Table 7 presents the 8 conditions of the PM2 with an accuracy of 77.03\%. For example, if the student thinks that the collaborative wall facilitates much the dissemination of information, has an age $\leq 16.5$ and is a man then the use of the collaborative wall facilitates very much the learning process of global climate change. On the other hand, if the student thinks that the collaborative wall facilitates very 
much the dissemination of information and has an age $\leq 17.5$ then the use of the collaborative wall facilitates very much the learning process of global climate change.

Table 7. Conditions of the PM2 about the use of the collaborative wall.

\begin{tabular}{ccccc}
\hline No. & $\begin{array}{c}\text { Collaborative wall } \rightarrow \\
\text { dissemination of information }\end{array}$ & Age & Sex & $\begin{array}{c}\text { Collaborative wall } \rightarrow \\
\text { learning process }\end{array}$ \\
\hline 1 & Very much & $\leq 17.5$ years & - & Very much \\
2 & Very much & $>17.5$ years & Man & Very much \\
3 & Very much & $>19.5$ years & Woman & Very much \\
4 & Very much & $\leq 19.5 \&>17.5$ years & Woman & Very little \\
5 & Much & $>16.5$ years & - & Very much \\
6 & Much & $\leq 16.5$ years & Man & Very much \\
7 & Much & $\leq 16.5$ years & Woman & Much \\
8 & Little & - & - & Much \\
\hline
\end{tabular}

\subsection{Motivation of the students}

The use of the collaborative wall increases very much $(n=49,66.22 \%)$, much $(n=13$, $17.57 \%)$, little $(n=5,6.76 \%)$ and very little $(n=7,9.46 \%)$ the motivation of the students during the educational process of global climate change (See Table 2).

The results of machine learning with 50\% (0.726), 60\% (0.629) and 70\% (0.679) of training indicate that $\mathrm{H}_{3}$ is accepted (See Table 4). Therefore, the organization of ideas in the collaborative wall positively influences the motivation of the students during the educational process of global climate change.

Table 8 presents the 7 conditions of the $\mathrm{PM}_{3}$ with an accuracy of $71.62 \%$. For example, if the student thinks that the collaborative wall facilitates much the organization of ideas, has an age $\leq 16.5$ years and is a woman, then the use of the collaborative wall increases much the motivation of the students during the educational process of global climate change. On the other hand, if the student thinks that the collaborative wall facilitates much the organization of ideas, has an age $\leq 16.5$ years and is a man then the use of the collaborative wall increases very much the motivation of the students during the educational process of global climate change. 
Table 8. Conditions of the PM3 about the use of the collaborative wall.

\begin{tabular}{ccccc}
\hline No. & $\begin{array}{c}\text { Collaborative wall } \rightarrow \\
\text { organization of ideas }\end{array}$ & Age & Sex & $\begin{array}{c}\text { Collaborative wall } \rightarrow \\
\text { motivation }\end{array}$ \\
\hline 1 & Very much & - & - & Very much \\
2 & Much & $>17.5$ years & - & Very much \\
3 & Much & $\leq 17.5 \&>16.5$ years & Man & Much \\
4 & Much & $\leq 16.5$ years & Man & Very much \\
5 & Much & $\leq 17.5 \&>16.5$ years & Woman & Very much \\
6 & Much & $\leq 16.5$ years & Woman & Much \\
7 & Little & - & - & Very little \\
\hline
\end{tabular}

The results of machine learning with $50 \%(0.584), 60 \%(0.731)$ and $70 \%(0.766)$ of training indicate that $\mathrm{H}_{4}$ is accepted (See Table 4). Therefore, the dissemination of information in the collaborative wall positively influences the motivation of the students during the educational process of global climate change.

Table 9 presents the 7 conditions of the PM4 with the accuracy of $72.97 \%$. For example, if the student thinks that the collaborative wall facilitates much the dissemination of information and has an age $>16.5$ years then the use of the collaborative wall increases very much the motivation of the students during the educational process of global climate change. On the other hand, if the student thinks that the collaborative wall facilitates much the dissemination of information and has an age $\leq 15.5$ years then the use of the collaborative wall increases much the motivation of the students during the educational process of global climate change.

Table 9. Conditions of the PM4 about the use of the collaborative wall.

\begin{tabular}{ccccc}
\hline No. & $\begin{array}{c}\text { Collaborative wall } \rightarrow \\
\text { dissemination of information }\end{array}$ & Age & Sex & $\begin{array}{c}\text { Collaborative wall } \rightarrow \\
\text { motivation }\end{array}$ \\
\hline 1 & Very much & - & - & Very much \\
2 & Much & $>16.5$ years & - & Very much \\
3 & Much & $\leq 16.5 \&>15.5$ years & - & Very much \\
4 & Much & $\leq 15.5$ years & - & Much \\
5 & Little & $>16.5$ years & Man & Much \\
6 & Little & $>16.5$ years & Woman & Little \\
7 & Little & $\leq 16.5$ years & - & Very little \\
\hline
\end{tabular}




\subsection{Interest of the students}

The use of the collaborative wall increases very much $(n=45,60.81 \%)$, much $(n=19$, $25.68 \%)$, little $(n=8,10.81 \%)$ and very little $(n=2,2.70 \%)$ the interest of the students during the educational process of global climate change (See Table 2). The results of machine learning with 50\% (0.675), 60\% (0.583) and 70\% (0.594) of training indicate that the $\mathrm{H}_{5}$ is accepted (See Table 4 ). Therefore, the organization of ideas in the collaborative wall positively influences the interest of the students during the educational process of global climate change.

Table 10 presents the 7 conditions of the PM5 with an accuracy of $70.27 \%$. For example, if the student thinks that the collaborative wall facilitates much the organization of ideas, has an age $\leq 16.5$ years and is a woman, then the use of the collaborative wall increases much the interest of the students during the educational process of global climate change. On the other hand, if the student thinks that the collaborative wall facilitates much the organization of ideas, has an age $\leq 16.5$ years and is man then the use of the collaborative wall increases very much the interest of the students during the educational process of global climate change.

Table 10. Conditions of the PM5 about the use of the collaborative wall.

\begin{tabular}{ccccc}
\hline No. & $\begin{array}{c}\text { Collaborative wall } \rightarrow \\
\text { organization of ideas }\end{array}$ & Age & Sex & $\begin{array}{c}\text { Collaborative wall } \rightarrow \\
\text { interest }\end{array}$ \\
\hline 1 & Very much & - & - & Very much \\
2 & Much & $>17.5$ years & - & Little \\
3 & Much & $\leq 17.5 \&>16.5$ years & Man & Little \\
4 & Much & $\leq 16.5$ years & Man & Very much \\
5 & Much & $\leq 17.5 \&>16.5$ years & Woman & Very much \\
6 & Much & $\leq 16.5$ years & Woman & Much \\
7 & Little & - & - & Little \\
\hline
\end{tabular}

The results of machine learning with 50\% (0.678), 60\% (0.806) and 70\% (0.800) of training indicate that the $\mathrm{H} 6$ is accepted (See Table 4). Therefore, the dissemination of information in the collaborative wall positively influences the interest of the students during the educational process of global climate change.

Table 11 presents the 6 conditions of the PM6 with an accuracy of $74.32 \%$. For example, if the student thinks that the collaborative wall facilitates much the dissemination of information and has an age $\leq 16.5$ years then the use of the collaborative wall increases much the interest of the students during the educational process of global climate change. On the other hand, if the student thinks that the 
collaborative wall facilitates very much the dissemination of information then the use of the collaborative wall increases very much the interest of the students during the educational process of global climate change.

Table 11. Conditions of the PM6 about the use of the collaborative wall.

\begin{tabular}{ccccc}
\hline No. & $\begin{array}{c}\text { Collaborative wall } \rightarrow \\
\text { dissemination of information }\end{array}$ & Age & Sex & $\begin{array}{c}\text { Collaborative wall } \rightarrow \\
\text { interest }\end{array}$ \\
\hline 1 & Very much & - & - & Very much \\
2 & Much & $>17.5$ years & - & Little \\
3 & Much & $\leq 17.5 \&>16.5$ years & - & Very much \\
4 & Much & $\leq 16.5$ years & - & Much \\
5 & Little & - & Man & Little \\
6 & Little & - & Woman & Much \\
\hline
\end{tabular}

\subsection{Perception of the students}

New technologies are promoting the construction of new virtual spaces that favor the learning process. For example, the collaborative wall facilitated the assimilation of knowledge about the global climate change.

"Better learning and more reasoning" (Student 18, man, 16 years old).

"It helped me to understand the topic more" (Student 20, woman, 16 years old).

"It helped me to organize my ideas and understand the class in an easier way"

(Students 40, woman, 16 years old).

According to the students of the National Preparatory School No. 7 "Ezequiel A. Chávez", the use of the collaborative wall allowed the analysis of ideas about the global climate change in the classroom.

"In a group, we analyze the opinions" (Student 19, woman, 18 years old).

"We analyze the issues with classmates to have a broader understanding and learn other opinions" (Student 23, woman, 16 years old).

"It allows increasing the capacity for analysis and understanding" (Student 43, man, 17 years old).

Technology allows that students have a leading role during the realization of the school activities. In fact, the students of the Biology IV course actively participate in the classroom through the collaborative wall. 
"Share ideas and opinions with all my classmates, understand and have a motivation to know about the information of the course" (Student 46, woman, 16 years old).

“Creativity, participation and collaboration" (Student 55, man, 16 years old).

"It encourages the group participation" (Student 64, woman, 16 years old).

Teachers can use the collaborative wall to create new learning and teaching spaces. In particular, the students of the National Preparatory School No. 7 "Ezequiel A. Chávez" mention that the use of the collaborative wall is fun.

"It helps us understand the topics. It's fun because it's interactive" (Student 21, woman, 16 years old).

"Classes become more didactic and fun" (Student 42, woman, 16 years old).

"A new way of using technology for education. It generates interest and is not boring" (Student 45, woman, 15 years old).

Advances in technology are transforming the roles of teachers and students in education. For example, the incorporation of the collaborative wall in the Biology IV course allowed the debate and exchange of ideas about the global climate change.

"A debate is created and different opinions are presented that help to understand the information" (Student 9, woman, 16 years old).

"Understand the ideas from different points of view" (Student 14, woman, 16 years old).

"It allows the exchange of ideas and opinions. We reach the conclusions" (Student 74, man, 16 years old).

Finally, teachers can use technology to create and conduct creative school activities. In particular, the collaborative wall allowed that students work as a team during the learning process about the global climate change.

"All work together" (Student 15, man, 16 years old).

"Learning and teamwork" (Student 33, man, 16 years old).

"Working as a team" (Student 44, man, 16 years old).

Figure 5 shows the word cloud about the perceptions of the students during the use of the collaborative wall. The words that present the highest frequency are 
understand, ideas, technology, change, students, fun, use, opinions, new, Biology, analysis, information, classmates, participation, debate, activities, help and classroom.

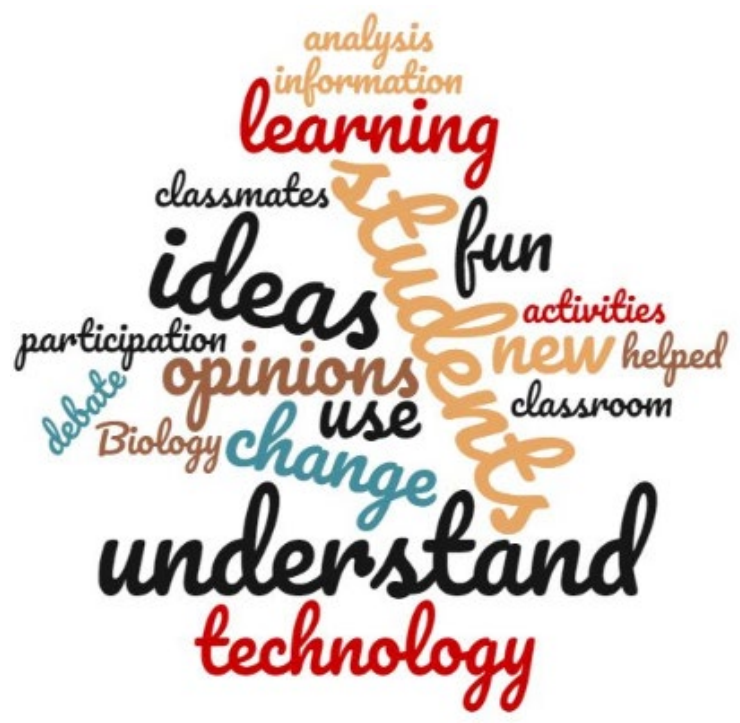

Figure 5. Word cloud about the use of the collaborative wall.

\section{Discussion}

The incorporation of technology in the educational field facilitates the planning, organization and implementation of new school activities (Almoeather, 2020; Benitez et al., 2020; Salas-Rueda, 2015). For example, Manrique et al. (2017) used digital tools in the Anatomy course in order to improve the teaching-learning conditions about Biology. Similar to Pardo-Cueva et al. (2020), the use of virtual walls in the Administration course facilitated the active role of the students. In particular, most of the students think that the collaborative wall facilitates very much the organization of ideas $(n=59,79.73 \%)$ and dissemination of information $(n=57,77.03 \%)$. Therefore, the students of the National Preparatory School No. 7 "Ezequiel A. Chávez" have a favorable opinion about the use of this technological tool in the Biology IV course.

\subsection{Learning process}

Various authors (e.g., Appleton \& Mackie, 2019; Poli et al., 2016; Shen et al., 2020) mention that technological advances such as website, educational software and web applications allow the realization of new school activities that facilitate the learning process about Biology. As Rashid, Yunus and Wahi (2019) indicated, virtual walls allow the construction of new virtual spaces that favor the learning. Most of the 
students ( $\mathrm{n}=53,71.62 \%)$ consider that the use of the collaborative wall facilitates very much the learning process of global climate change. As a result of the analysis performed, $17.57 \%$ of the students $(n=13)$ thinks that the use of the collaborative wall facilitates much the learning process of global climate change. Therefore, $89.19 \%$ of the students have a favorable opinion about the use of this technological tool in the Biology IV course.

This study shares the ideas of various authors (e.g., Pardo-Cueva et al., 2020; Rashid, Yunus, \& Wahi, 2019; Sangeetha, 2016) about the use of virtual walls to innovate the school activities in the classroom. The results of machine learning on $\mathrm{H} 1$ are higher than 0.130 , therefore, the organization of ideas in the collaborative wall positively influences the learning process of global climate change. Data science identifies 9 conditions of the PM1 with an accuracy of $74.32 \%$. In this predictive model, the Age and Sex of the students determine how the collaborative wall influences the learning process of global climate change. The decision tree technique identifies 6 conditions where the use of the collaborative wall facilitates very much the learning process of global climate change. For example, if the student thinks that the collaborative wall facilitates very much the organization of ideas and has an age $\leq 17.5$ years then the use of the collaborative wall facilitates very much the learning process of global climate change. On the other hand, the sex of the students allows identifying 5 conditions of the PM1. For example, if the student thinks that the collaborative wall facilitates very much the organization of ideas, has an age $>17.5$ years and is a man then the use of the collaborative wall facilitates very much the learning process of global climate change.

The results of machine learning on $\mathrm{H} 2$ are higher than 0.190, therefore, the dissemination of information in the collaborative wall positively influences the learning process of the global climate change. Data science identifies 8 conditions of the PM2 with an accuracy of 77.03\%. In this predictive model, the Age and Sex of the students determine how the collaborative wall influences the learning process of global climate change. The decision tree technique identifies 5 conditions where the use of the collaborative wall facilitates very much the learning process of global climate change. For example, if the student thinks that the collaborative wall facilitates very much the dissemination of information and has an age $\leq 17.5$ then the use of the collaborative wall facilitates very much the learning process of global climate change. On the other hand, the sex of the students allows identifying 5 conditions of the PM2. For example, if the student thinks that the collaborative wall 
facilitates very much the dissemination of information, has an age $>17.5$ and is a man then the use of the collaborative wall facilitates very much the learning process of global climate change.

\subsection{Motivation of the students}

In the field of Biology, ICTs allow the construction of new educational spaces that favor the motivation of students (Appleton \& Mackie, 2019; Rashid, Yunus, \& Wahi, 2019; Shen et al., 2020). According to Rashid, Yunus and Wahi (2019), the incorporation of the virtual wall in the Foreign Language course favored the motivation of the students. In the Biology IV course, most of the students $(n=49$, 66.22\%) think that the use of the collaborative wall increases very much the motivation of the students during the educational process of global climate change. Likewise, quantitative data reveals that the use of the collaborative wall increases much ( $\mathrm{n}=13,17.57 \%)$ the motivation of the students during the educational process of global climate change. Therefore, $83.79 \%$ of the students have a favorable opinion about the use of this technological tool in the Biology IV course.

Similar to Rashid, Yunus and Wahi (2019), the use of virtual walls in the Foreign Language course facilitated the creation of educational spaces where the students actively participated and increased their motivation during the learning process. The results of machine learning on $\mathrm{H}_{3}$ are higher than 0.620 , therefore, the organization of ideas in the collaborative wall positively influences the motivation of the students during the educational process of global climate change. Data science identifies 7 conditions of the PM3 with an accuracy of $71.62 \%$. In this predictive model, the Age and Sex of the students determine how the collaborative wall influences the motivation of the students. The decision tree technique identifies 4 conditions where the use of the collaborative wall increases very much the motivation of the students during the educational process of global climate change. For example, if the student thinks that the collaborative wall facilitates much the organization of ideas, has an age $\leq 16.5$ years and is a man then the use of the collaborative wall increases very much the motivation of the students during the educational process of global climate change. On the other hand, the sex of the students allows identifying four conditions of the PM3. For example, if the student thinks that the collaborative wall facilitates much the organization of ideas, has an age $\leq 16.5$ years and is a woman, then the use of the collaborative wall increases much the motivation of the students during the educational process of global climate change. 
The results of machine learning on $\mathrm{H}_{4}$ are higher than 0.580 , therefore, the dissemination of information in the collaborative wall positively influences the motivation of the students during the educational process of global climate change. Data science identifies 7 conditions of the PM4 with an accuracy of $72.97 \%$. In this predictive model, the Age and Sex of the students determine how the collaborative wall influences the motivation of the students. The decision tree technique identifies 3 conditions where the use of the collaborative wall increases very much the motivation of the students during the educational process of global climate change. For example, if the student thinks that the collaborative wall facilitates much the dissemination of information and has an age $>16.5$ years then the use of the collaborative wall increases very much the motivation of the students during the educational process of global climate change. On the other hand, the sex of the students allows identifying 2 conditions of the PM4. For example, if the student thinks that the collaborative wall facilitates little the dissemination of information, has an age $>16.5$ years and is a woman then the use of the collaborative wall increases little the motivation of the students during the educational process of global climate change.

\subsection{Interest of the students}

Technological advances are transforming the functions and attitudes of students during the performance of school activities in the field of Biology (Appleton \& Mackie, 2019; Salas-Rueda \& Vázquez-Estupiñán, 2018; Shen et al., 2020). Most of the students ( $n=45,60.81 \%$ ) consider that the use of the collaborative wall increases very much the interest of the students during the educational process of global climate change. Also, $25.68 \%$ of the students $(n=19)$ think that the use of the collaborative wall increases much the interest of the students during the educational process of global climate change. Therefore, $86.49 \%$ of the students have a favorable opinion about the use of this technological tool in the Biology IV course.

In the English Language course, the use of the virtual wall improved the interaction between the participants of the educational process and facilitated the active role of the students in the classroom (Sangeetha, 2016). The results of machine learning on the $\mathrm{H}_{5}$ are higher than 0.580 , therefore, the organization of ideas in the collaborative wall positively influences the interest of the students during the educational process of global climate change. Data science identifies 7 conditions of the PM5 with an accuracy of $70.27 \%$. In this predictive model, the Age and Sex of the 
students determine how the collaborative wall influences the interest of the students. The decision tree technique identifies 3 conditions where the use of the collaborative wall increases very much the interest of the students during the educational process of global climate change. For example, if the student thinks that the collaborative wall facilitates much the organization of ideas, has an age $\leq 16.5$ years and is man then the use of the collaborative wall increases very much the interest of the students during the educational process of global climate change. On the other hand, the sex of the students allows identifying 4 conditions of the PM5. For example, if the student thinks that the collaborative wall facilitates much the organization of ideas, has an age $\leq 16.5$ years and is woman then the use of the collaborative wall increases much the interest of the students during the educational process of global climate change.

The results of machine learning on the H6 are higher than 0.670 , therefore, the dissemination of information in the collaborative wall positively influences the interest of the students during the educational process of global climate change. Data science identifies 6 conditions of the PM6 with an accuracy of 74.32\%. In this predictive model, the Age and Sex of the students determine how the collaborative wall influences the interest of the students. The decision tree technique identifies 2 conditions where the use of the collaborative wall increases very much the interest of the students during the educational process of global climate change. For example, if the student thinks that the collaborative wall facilitates very much the dissemination of information then the use of the collaborative wall increases very much the interest of the students during the educational process of global climate change. On the other hand, the sex of the students allows identifying two conditions of the PM6. For example, if the student thinks that the collaborative wall facilitates little dissemination of information and is a man, then the use of the collaborative wall increases little the interest of the students during the educational process of global climate change.

\subsection{Perception of the students}

Technological advances such as web applications are causing that teachers organize and carry out new school activities. In particular, the use of the collaborative wall in the Biology IV course facilitated the assimilation of knowledge about the global climate change, the active participation of the students in the classroom and the construction of fun educational spaces. 
Teachers have the opportunity to use virtual walls during the school activities in order to improve the teaching-learning conditions because this technological tool allows the communication between the participants of the educational process through the organization of ideas and dissemination of information in the classroom.

Even the incorporation of the collaborative wall in the National Preparatory School No. 7 "Ezequiel A. Chávez" facilitated the analysis, debate and exchange of ideas about the global climate change in the classroom. Finally, the collaborative wall allowed that the students work as a team during the learning process.

\section{Conclusion}

Technological advances are changing the way of organizing and conducting the school activities in the 21st century. In particular, the collaborative wall allows the active participation of students in the classroom. The results of machine learning indicate that the organization of ideas and dissemination of information in the collaborative wall positively influence the learning process of global climate change, motivation and interest of the students. Also, data science identifies 6 predictive models about the use of the collaborative wall in the field of Biology through the decision tree technique.

This research recommends the incorporation of the collaborative wall in the school activities because this web application allows the active role of the student in the classroom through the collaborative work. In fact, the use of the collaborative wall in the Biology IV course facilitated the assimilation of knowledge about the global climate change, participation of the students during the face-to-face sessions and construction of educational virtual spaces.

The limitations of this research are the use of the collaborative wall in the field of Biology, size of the sample and analysis of this technological tool in the learning process about global climate change, motivation and interest of the students. Therefore, future research can analyze the impact of the collaborative wall in the areas of engineering, education, medicine, computer science, management and marketing. Also, teachers can analyze how the collaborative wall influences the development of skills and the satisfaction of students in high schools and universities.

The implications of this study are related to the incorporation of virtual walls in school activities in order to improve the teaching-learning conditions and organize new school activities focused on students. In conclusion, technology allows the construction of new spaces for learning and teaching. In particular, the collaborative wall is a web application that allows the active participation of students and facilitates 
the discussion of ideas in the classroom through the organization, dissemination and use of images and information.

\section{Acknowledgements}

This work was supported by UNAM-DGAPA-PAPIME (Project Support Program to Innovate and Improve Education) PE106419 (El Aula del Futuro: de la Escuela Nacional Preparatoria 7). This research is grateful for the support of the teacher of the Biology IV course.

\section{References}

Almoeather, R. (2020). Effectiveness of Blackboard and Edmodo in Self-Regulated Learning and Educational Satisfaction. Turkish Online Journal of Distance Education, 21(2), 126-140.

Appleton, L. \& Mackie, J. (2019). Using Digital Organism Evolutionary Software in the Classroom. The American Biology Teacher, 81(1), 12-17. https://doi.org/10.1525/abt.2019.81.1.12

Benitez, C., Quinones, A., Gonzalez, P., Ochoa, C., \& Vargas, A. (2020). The Impact of Online Annotation Tools on Students' Academic Performance in a Distance University Program. Turkish Online Journal of Distance Education, 21(2), 167-177.

Bidarra, J. \& Rusman, E. (2017). Towards a pedagogical model for science education: bridging educational contexts through a blended learning approach. Open Learning: The Journal of Open, Distance and e-Learning, 32(1), 6-20. https://doi.org/10.1080/02680513.2016.1265442

De-Witt, D., Alias, N., Ibrahim, Z., Shing, N. K., \& Rashid, S. M. (2015). Design of a Learning Module for the Deaf in a Higher Education Institution Using Padlet. Procedia, 176, 220226.

Elekaei, A., Tabrizi, H. H., \& Chalak, A. (2020). Evaluating Learners' Vocabulary Gain and Retention in an E-Learning Context Using Vocabulary Podcasting Tasks: A Case Study. Turkish Online Journal of Distance Education, 21(2), 190-203.

Gamboa-Rodríguez, F. (2015). Diseño de espacios colaborativos interactivos para el aprendizaje. En J. Zubieta-García y C. Rama-Vitale (Eds.), La educación a distancia en México: Una nueva realidad universitaria (pp. 201-212), México, UNAM.

Galimullina, E., Ljubimova, E., \& Ibatullin, R. (2020). SMART education technologies in mathematics teacher education - ways to integrate and progress that follows integration. Open Learning: The Journal of Open, Distance and e-Learning, 35(1), 4-23. https://doi.org/10.1080/02680513.2019.1674137

Han, W. (2018). A Fundamentals of Financial Accounting Course Multimedia Teaching System based on Dokeos and BigBlueButton. International Journal of Emerging Technologies in Learning, 13(5), 141-152. https://doi.org/10.3991/ijet.v13io5.8433

Lysne, S. J. \& Miller, B. G. (2015). Using Mobile Devices to Engage Students in Evolutionary Thinking. The American Biology Teacher, 77(8), 624-627.

https://doi.org/10.1525/abt.2015.77.8.10

Manrique, C., Grostieta-Dominguez, Z. V., Rojas-Ruiz, R., Alencastre-Miranda, M., Muñoz-Gómez, L., \& Silva-Muñoz, C. (2017). A Portable Augmented-Reality Anatomy Learning System 
Using a Depth Camera in Real Time. The American Biology Teacher, 79(3), 176-183. https://doi.org/10.1525/abt.2017.79.3.176

Paepe, L. D., Zhu, C., \& Depryck, K. (2018). Online Dutch L2 learning in adult education: educators' and providers' viewpoints on needs, advantages and disadvantages. Open Learning: The Journal of Open, Distance and e-Learning, 33(1), 18-33. https://doi.org/10.1080/02680513.2017.1414586

Pardo-Cueva, M., Chamba-Rueda, L. M., Higuerey-Gómez, A., \& Jaramillo-Campoverde, B. G. (2020). ICT and academic performance in higher education: A relationship enhanced by the use of the Padlet. Revista Ibérica de Sistemas e Tecnologias de Informação, 28, 934-945.

Poli, D. B., Stoneman, L., Siburn, A., Bader, W., \& Clarke, E. (2016). Using MapBox Software to Help Students See Trends in Biology. The American Biology Teacher, 78(5), 426-427. https://doi.org/10.1525/abt.2016.78.5.426

Rashid, A., Yunus, M., \& Wahi, W. (2019) Using Padlet for Collaborative Writing among ESL Learners. Creative Education, 10, 610-620.

Salas-Rueda, R. A. (2020). Use of the flipped classroom to design creative and active activities in the field of Computer science. Creativity studies, 13(1), 136-151.

Salas-Rueda, R. A. (2018). Perspectivas de los estudiantes sobre la inclusión de videojuegos en el aprendizaje. International Journal of Educational Research and Innovation (IJERI), 1O, $163-178$.

Salas-Rueda, R. A. (2015). Interfaz web usable: herramienta tecnológica para el proceso de enseñanza-aprendizaje. Revista de Comunicación de la SEECI, 36, 148-177.

Salas-Rueda, R. A., De-La-Cruz-Martínez, G., Alvarado-Zamorano, C., \& Gamboa-Rodríguez, F. (2020). Mobile devices and Collaborative wall: Media to innovate the teaching-learning process on social sciences? Meta: Avaliacao, 12(36), 601-624.

Salas-Rueda, R. A., Ramírez-Ortega, J., \& Eslava-Cervantes, A. L. (2021). Use of the Collaborative Wall to Improve the Teaching-Learning Conditions in the Bachelor of Visual Arts.

Contemporary Educational Technology, 13(1), ep286.

https://doi.org/10.30935/cedtech/8711

Salas-Rueda, R. A. \& Vázquez-Estupiñán, J. J. (2018). Aplicación en la nube Lucidchart: ¿herramienta necesaria para la innovación del proceso educativo en el siglo XXI? Revista de Comunicación de la SEECI, 44, 115-126.

Sangeetha, S. (2016). Edmodo and Padlet as a collaborative online tool in Enriching Writing Skills in Language Learning and Teaching. Global English-Oriented Research Journal, 1(4), 178184 .

Shen, J., Xiang, Z., Peijing, Y., \& Zixuan, Z. (2020). Searching for the Source of Infection: A Website to Help Teach the Principles of Infectious Disease. The American Biology Teacher, 82(1), 37-42.

Wang, X. \& Fan, C. (2018). A Computer Experiment Teaching System Based on OMAP Embedded System. International Journal of Emerging Technologies in Learning, 13(5), 188-200. https://doi.org/10.3991/ijet.v13io5.8439

Whalley, R. \& Barbour, M. K. (2020). Collaboration and Virtual Learning in New Zealand Rural Primary Schools: A Review of the Literature. Turkish Online Journal of Distance Education, 21(2), 102-125.

Xia, C. (2018). Multimedia Teaching Platform Construction Based on Flash Interaction Technology for Gymnastics. International Journal of Emerging Technologies in Learning, 13(5), 224-235. https://doi.org/10.3991/ijet.v13io5.8441

Zhang, Z. (2018). Construction of the Multimedia Teaching Platform of Cost Accounting Course Based on EXCEL VBA Program. International Journal of Emerging Technologies in Learning, 13(5), 177-187. https://doi.org/10.3991/ijet.v13io5.8436 